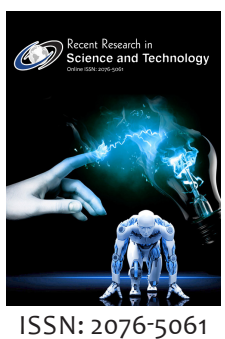

*Corresponding Author: N. M. Ha-Mim Email:nurhamimurp15@ gmail.com

\section{Differential climate change vulnerability among different poverty groups in southwestern Bangladesh: lessons for adaptation planning}

\author{
N. M. Ha-Mim*, M. Z. Hossain \\ Urban and Rural Planning Discipline, Khulna University, Khulna-9208, Bangladesh
}

\begin{abstract}
This article draws on research findings from fieldwork undertaken in Mongla Upazila of Southwest Bangladesh from 2018 to 2019 to analyse how climate-related vulnerability and adaptation is differentiated among different poverty groups. The principal aim of this research is to investigate complex relationship between vulnerability, poverty, and adaptation in a case study carried out in two rural cyclone-prone areas of southwest Bangladesh, focusing on household level vulnerability and adaptive responses to climate change. The quantitative research strategy was adopted in this research. Specific methods utilized for the data collection process included in-depth questionnaire survey of 98 households. The significance of the results was in the differences of poverty and adaptation choices of the households with differential climate change vulnerability which revealed a complex relationship within vulnerability, poverty and adaptation. This research also highlighted that the poor households with high vulnerability could highly be adaptive through adopting a significant number of adaptations to deal with sudden and gradual changes in climate, but the results also suggest that households who are not poor who have usually low vulnerability, likely to have less adaptive responses than households who have high vulnerability. Moreover, this research is an attempt to reveal the complex relationship among vulnerability, poverty and adaptation that may help to develop more effective adaptation framework than before to deal with climate variability and change.
\end{abstract}

KEYWORDS: Climate change, vulnerability, poverty, adaptation and southwest Bangladesh

\section{INTRODUCTION}

The new paradigm governing disaster risk reduction framework lie at the core understanding of poverty, vulnerability and adaptation nexus. This is why analysing vulnerability and adaptation of poor coastal households has gained currency in the recent time by the scientific community and scholarship on this diverse setting is growing. In climate change arena, most people have an idea that poor people who are living in the coastal area of Bangladesh are more vulnerable and less adaptive to the gradual and sudden change of climate and which over the time has become a common stereotype towards the poor community. This research is framed to contribute in this integrated thinking of poverty, vulnerability and adaptation which may retain our common stereotype towards the poor or break it.

The concept of poverty, vulnerability and adaption are inherently linked but distinct. Poverty is narrowly defined as economic welfare previously but after introducing Amartya Sen`s capability approach in 1980s it is broadly viewed in terms of freedom, entitlements, capabilities and human wellbeing [1]. According to Amartya Sen, poverty that people experience in their everyday life results from their capability deprivation which leads them to lack of entitlements and functioning [2]. This understanding of poverty also highlighted vulnerability conceptualization, as Amartya Sen in 1981 explained vulnerability focusing on famine and food insecurity where production failure and food shortage leads people to limited capabilities and entitlements $[3,4]$.

In most of the case the adaptation practices are influenced by the vulnerability context of the household. Sometime household became more innovative to deal with certain types of vulnerability and these is how different types of adaptation practices are introduced within the community to make themselves more resilient into that particular sorts of vulnerability. A case of Brazilian Amazon shows similar findings where Caboclos communities is an increase in the river flows and very high flood levels which inundated village causing serious destruction of the resources which can possibility linked with

Copyright: $\odot$ The authors. This article is open access and licensed under the terms of the Creative Commons Attribution License (http://creativecommons.org/licenses/by/4.0/) which permits unrestricted, use, distribution and reproduction in any medium, or format for any purpose, even commercially provided the work is properly cited. Attribution - You must give appropriate credit, provide a link to the license, and indicate if changes were made. 
the impact of climate change. In such condition people are adopting trough temporary migration to the towns and taking advantage of the kinship relationship $[5,6]$.

However, understanding of social, economic and political adaptation in the context of poverty and vulnerability condition of the coastal households are limited. This paper represents an empirical investigation of the nexus between poverty. vulnerability and adaptation to climate change through the case studies carried out in two tropical cyclone prone coastal areas of Bangladesh where differential components of vulnerability and adaptation of the coastal households are analysed in between the poor and non-poor sections of the community. This research will help us to incorporate an effective pro-poor adaptation framework as well as a holistic disaster risk reduction system in the future.

\section{METHODOLOGY}

\section{Study Area}

For this study, data were collected from Chila and Burirdanga union of Mongla Upazila under Bagerhat district which is located in between $22^{\circ} 20^{\prime} 55.687^{\prime \prime}$ and 22 $34^{\prime} 33.198^{\prime \prime}$ north latitudes and in between 89.33'26.107' and 89.43'10.86" east longitudes. These two unions are flanked by the Sundarbans and Bay of Bangle in the south and Poshur river in the west.

\section{Sample Size, Sampling Technique and Data Collection}

In this research the unit of analysis was the household and the household head were the key informant. Taro Yamane`s (1967) [7] simplified formula was used to determine the sample size and stratified random sampling technique was used for the collection of data in the field. A total of 98 households were surveyed in between August 01-August 30, 2018 using a structured questionnaire at $90 \%$ confidence level.

\section{Analytical Framework}

Indexing Method ${ }^{1}$ : To identify vulnerability score for each of the households and categorizing them in terms of their vulnerability, the household level livelihood vulnerability index (LVI) is calculated. It includes normalization of the collected sub-components data to make it comparable, calculation of the value of major components and calculation of the livelihood vulnerability index value for each of the households considering the weighted average of the three major components. The households are then categorized into two categories based on their vulnerability index value where the cut off value was average LVI (households < average LVI = lowly vulnerable, households $\geq$ average LVI = highly vulnerable). The variables

$1 \quad$ This research followed the indexing method of the paper published in International Conference on Disaster Risk Management 2019, authored by N.M. Ha-Mim, M.Z. Hossain \& S.M. Moniruzzaman and titled as Asset Based Profile Approach for Understanding Differentiated Vulnerability and Resilience of Coastal Households in the Context of Climate Change' [8]. used for calculation of livelihood vulnerability index at household level are listed in Appendix (Table 1).

Measuring Poverty: To reflect the changes in cost of living across the world the global poverty line is updated from $\$ 1.25$ to $\$ 1.90$ in October 2015. This research adopted $\$ 1.90$ poverty line as reference to categorize households in between poor and non-poor. If total consumption per adult equivalent per day is less than \$1.9 then the household is registered as poor whether non-poor as according to World Bank (Eq. 1 and Eq. 2). Here, adult equivalent (Eq. 3) is used to consider difference in need by age and economic of scales in consumption which is adopted from OECD scale.

$$
\frac{C}{H S(A E) \times 30}<\$ 1.9=\text { Poor }(\$ 1=83.98 \text { Tk, Date: } 14.03 .2018)(1)
$$

$$
\frac{C}{H S(A E) \times 30} \geq \$ 1.9=\text { Non }- \text { poor }
$$

$$
\text { HS }(\mathrm{AE})=1+0.7\left(\mathrm{~N}_{\text {adults }}-1\right)+0.5 \mathrm{~N}_{\text {children }}
$$

Here, $\mathrm{C}$ is total consumption per month, $\mathrm{HS}(\mathrm{AE})$ is household size in adult equivalent, $N_{\text {adultsis }}$ is number of adult members in the household and $N_{\text {childrenis }}$ is the number of children in the household.

Unadjusted BLR: Poor and non-poor category of households are used as dependent variable and each of the adaptation practices are used as independent variable to conduct the Binary Logistic Regression (BLR). Here, BLR is conducted for each of the individual variable rather than considering the influence of other variables as the focus of this research is to identify the adaptation differential among poor and non-poor households for each of the variable separately, not to identify the influential variables where considering the effect of other variables is the must, which is also called an unadjusted BLR. It is also to make the understanding simple and clear through providing exact odds ratio of the corresponding variable without being adjusted by other covariance.

\section{RESULTS AND DISCUSSIONS}

\section{Differential Vulnerability among Different Poverty Groups}

The livelihood vulnerability index (LVI) is juxtaposed with poverty category here, so as to classify households in terms of these two attributes and to identify vulnerability differential among different poverty groups. The result of the juxtaposition is shown in Figure 1. Four possible categories are identified for this juxtaposition into which households can be placed according to their vulnerability and poverty characteristics. These could be respectively represented as poor households with high vulnerability, non-poor households with high vulnerability, poor households with low vulnerability and nonpoor households with low vulnerability. 


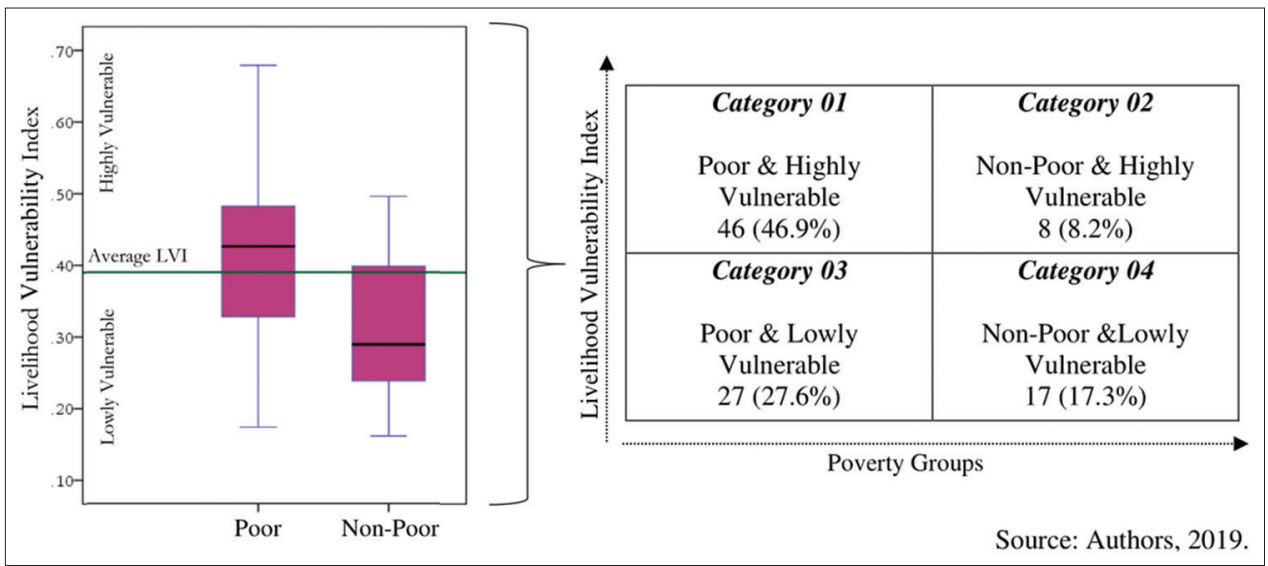

Figure 1: Vulnerability and poverty attributes, juxtaposed

These findings show that the poor households can also have low vulnerability and the non-poor households can also be in highly vulnerable category which is beyond our common idea that the poor households will always be in the highly vulnerable category and non-poor households will always be in lowly vulnerable category. The boxplot also shows that the maximum non-poor households are in the lowly vulnerable category though a least are in the highly vulnerable category where for the poor households a large portion registered themselves in lowly vulnerable category along with registered in the highly vulnerable category.

As shown in Figure 1. 46.9\% households are registered in poor and highly vulnerable category (category 01 ) and are in urgent need of assistance and should be in the highest priority when an extreme weather event will be happened. It also reveals that $8.2 \%$ households are non-poor based on poverty measures, but are in highly vulnerable category (category 02 ) as they have less social, political and physical measures that will contribute to their capacity to bounce back. $27.6 \%$ are in poor and lowly vulnerable category (category 03 ) and $17.3 \%$ of the households are in non-poor and lowly vulnerable category (category 4). In decision making consideration of the both vulnerability and poverty attributes of the households is the must for taking appropriate policy measures.

\section{Unadjusted BLR to Understand the Differential Adaptation among Different Poverty Groups}

To explore the adaptation differential among different poverty groups mainly 25 variables are considered to conduct the unadjusted Binary Logistic Regression, which is shown in Table 1. After a bivariate correlation, the variables 'keeping poultry inside house during hazard time' and 'special techniques for hazards mitigation' were removed from the BLR because of their strong collinearity with 'fish ponds protected with nets and barriers' and 'adopting climate resilient crop type', respectively. At this point, the total BLR variable turned down to 23 from 25. Furthermore, the cross-tabulation with the dependent variable 'use canal for irrigation', 'adopting floating agriculture techniques' and 'building rain water reservoir in the house' has identified cell frequency less than 5 . These three variables were excluded to meet the condition of data sufficiency test. Finally, 20 variables were entered to conduct the unadjusted BLR.

As shown in Table 1 , for some adaptation practices the Estimated (beta coefficient, B) value is positive and for some adaptation practices it is negative. The positive estimated value refers to the adaptation practices that is higher practiced by non-poor households and negative value refers the adaptation practices that is higher practiced by the poor households. It also elicits that, among 20 types of adaptation practices 11 types are higher practices by the poor households where for non-poor households it is only of 9 types. This is because of high frequency of taking that particular adaptation strategy by the poor households rather than the non-poor households. For more clarification of this adaptation difference among different poverty groups odds ratio is interpreted here.

The $\operatorname{Exp}(B)$ column shows the odds ratio and indicates that taking the adaptation strategies maintaining networks with political elites, adoption of weather information product, regular savings from family income, relocating fish cultivation area, changing irrigation techniques, repair and rebuild houses with hardy materials, change of housing location, elevated latrines to avoid spread of diseases and involving with community based water supply system are respectively 2.76, 24.67, 14.97, 1.85, $2.548,2.226,1.605,1.981$ and 2.045 times as likely to higher practice by the non-poor households than the poor households.

On the opposite side, being member of saving group, making coalitions with NGO `s, capacity building training, move animals to elevated platforms, fishing ponds protected with nets and barriers, adopt climate resilient crop types, making houses on raised plinths, elevated courtyard, cooking on elevated platform, planting trees around the house and conservation of mangrove plantation are the adaptation practices which is respectively $.645, .949, .853, .831, .903, .846, .867, .690, .358, .756$ and .564 times as likely to less practice by the non-poor households than the poor households. In this case poor households also proved to have significant number of adaptation practices in response to climatic hazards and change than the households who are non-poor which is making them resilient against the gradual and sudden change in climate. So, these findings break 
Table 1. Unadjusted BLR to understand the differential adaptation among different poverty groups Dependent Variable: 'Poor' (coded as 0 ) and 'Non-Poor' (coded as 1)

\begin{tabular}{|c|c|c|c|c|c|}
\hline $\begin{array}{l}\text { Variables of Adaptation } \\
(N=98)\end{array}$ & $\begin{array}{c}\text { B (beta } \\
\text { coefficient) }\end{array}$ & $\begin{array}{l}\text { Exp (B): } \\
\text { odds ratio }\end{array}$ & $\begin{array}{c}\text { Standard } \\
\text { error }\end{array}$ & $\begin{array}{c}\text { Wald } \\
\text { Chi- } \\
\text { square }\end{array}$ & Sig. \\
\hline Being member of saving group & -.438 & .645 & .510 & .738 & .390 \\
\hline $\begin{array}{l}\text { Household making coalitions with NGO`s/ } \\
\text { Donor`s organizations }\end{array}$ & -.053 & .949 & .464 & .013 & .910 \\
\hline $\begin{array}{l}\text { Attending capacity building training provided } \\
\text { by NGO/GO }\end{array}$ & -.159 & .853 & .466 & .116 & .733 \\
\hline Maintaining networks with political elites & 1.015 & 2.76 & .524 & 3.76 & $.053^{*}$ \\
\hline Adoption of weather information products & 3.205 & 24.67 & 1.05 & 9.37 & $.002 * *$ \\
\hline Regular savings from family income & 2.706 & 14.97 & .664 & 16.16 & $.000^{* * *}$ \\
\hline Move the animals to elevated platforms or land & -.185 & .831 & .520 & .126 & .723 \\
\hline Relocating fish cultivation area & .617 & 1.85 & .500 & 1.52 & .218 \\
\hline Fishing ponds protected with nets and barriers & -.103 & .903 & .721 & .020 & .887 \\
\hline Adopt climate resilient crop types & -.168 & .846 & .465 & .130 & .718 \\
\hline Changing irrigation techniques & .935 & 2.548 & .480 & 3.801 & $.051 *$ \\
\hline Making houses on raised plinths & -.143 & .867 & .586 & .060 & .807 \\
\hline Elevated courtyard & -.371 & .690 & .480 & .598 & .439 \\
\hline Repair or rebuild houses with hardy materials & .800 & 2.226 & .675 & 1.406 & .236 \\
\hline Change of housing location & .473 & 1.605 & .565 & .702 & .402 \\
\hline Elevated latrines to avoid spread of diseases & .684 & 1.981 & .605 & 1.275 & .259 \\
\hline $\begin{array}{l}\text { Cooking on elevated platforms General } \\
\text { arrangement }\end{array}$ & -1.027 & .358 & .657 & 2.442 & .118 \\
\hline $\begin{array}{l}\text { Involving with community-based water supply } \\
\text { system }\end{array}$ & .716 & 2.045 & .469 & 2.325 & .127 \\
\hline Planting trees around the house & -.280 & .756 & .466 & .361 & .548 \\
\hline Conservation of mangrove plantation & -.572 & .564 & .470 & 1.481 & .224 \\
\hline & & & & \multicolumn{2}{|c|}{ Source: Authors, 201} \\
\hline \multicolumn{6}{|c|}{$\begin{array}{l}\text { *Significant at } p \leq 0.10, * * \text { Significant at } p \leq 0.05, * * * \text { Significant at } p \leq 0.001 \\
\text { Legends: }\end{array}$} \\
\hline \multicolumn{6}{|c|}{ Adaptation practices that is higher practiced by poor households. } \\
\hline \multicolumn{6}{|c|}{ Adaptation practices that is higher practiced by non-poor households. } \\
\hline
\end{tabular}

our common stereotype, that the poor households are always less adaptive to climate change than the non-poor households.

\section{CONCLUSION}

This research examines the nexus between poverty, vulnerability and adaptation using the case study of a coastal sub-district in the context of climate change. The findings highlighted that both the poor and non-poor households who often experiences similar exposure to a climatic extreme, can have different level of vulnerability and adaptive response over the time. It also breaks our common stereotype that the poor households who are living in the vulnerable locations and have least capacity to withstand the impacts of extreme weather events, are always being more vulnerable and having less adaptations than nonpoor households. This research proves that the poor households could also be existed in the low vulnerable category because of having strong social and political network that contribute to their capacity to bounce back from the negative effects of extreme climatic events. It is found that they can develop more adaptive responses to deal with climatic stressors than that of non-poor households.

\section{REFERENCES}

1. Hick, R 2012, 'The capability approach: insights for a new poverty focus', Journal of social policy, vol. 41, pp. 291-308.

2. Sen, AK 2000, 'Development as freedom'.

3. Sen, AK 1981, 'Poverty and Famines: An Essay on Entitlement and Deprivation', Clarendon, Oxford.

4. Swift, J 1989, 'Why are rural people vulnerable to famine?', IDS Bulletin, pp. 8-15.

5. Marengo, J, Borma, L, Rodriguez, D, Pinho, P, Soares, W \& Alves, L 2013, 'Recent extremes of drought and flooding in Amazonia: 
vulnerabilities and human adaptation', American Journal of Climate Change, pp. 87-96.

6. Tomasella, J, Pinho, PF, Borma, LS, Marengo, JA, Nobre, CA, Bittencourt, OR et al. 2012, 'The droughts of 1997 and 2005 in Amazonia: floodplain hydrology and its potential ecological and human impacts', Climatic Change, pp. 1-24.
7. Yamane, T 1967, 'Statistics: An Introductory Analysis', New York: Harper and Row.

8. Ha-Mim, NM, Hossain, MZ \& Moniruzzaman, SM 2019, 'Asset Based Profile Approach for Understanding Differentiated Vulnerability and Resilience of Coastal Households in the Context of Climate Change', International Conference of Disaster Risk Management, pp. 363-368.

\section{APPENDIX}

Appendix Table 1: Variables used to calculate household level livelihood vulnerability index

\begin{tabular}{|c|c|c|c|}
\hline Major Components & Sub-Components & $\begin{array}{l}\text { Functional } \\
\text { Relationship }\end{array}$ & $\begin{array}{l}\text { Unit of } \\
\text { Measurement }\end{array}$ \\
\hline Physical & Number of natural disasters during the last 10 years & Positive & Count \\
\hline \multirow[t]{18}{*}{ Vulnerability (19) } & Av. Months/days homesteads remained inundated due to cyclone or flooding & Positive & Days \\
\hline & Duration of stagnant water due to rain or flood & Positive & Days \\
\hline & Duration of waterlogging in the agriculture field & Positive & Days \\
\hline & Frequency of flash flood & Positive & Count \\
\hline & Average height of water during flood & Positive & Feet \\
\hline & Average time to reach nearest health centre & Positive & Minute \\
\hline & Average time to reach nearest vehicle station & Positive & Minute \\
\hline & Average cost of reaching health centre & Positive & Taka \\
\hline & Acreage of land ownership & Negative & Acre \\
\hline & Average time to reach to the cyclone shelter & Positive & Minute \\
\hline & Chance of losing land due to river erosion & Positive & Yes/No \\
\hline & Unavailability of vehicles to evacuate people and livestock & Positive & Yes/No \\
\hline & Do not have access to food relief in disaster time & Positive & Yes/No \\
\hline & Do not have access to early warning system (Independent/ Conventional) & Positive & Yes/No \\
\hline & $\begin{array}{l}\text { Drinking water sources frequently affected by natural hazards such as drought, heavy } \\
\text { rains and sudden storms, cyclone \& storm surge. }\end{array}$ & Positive & Yes/No \\
\hline & Households don't have vehicles to use for evacuation & Positive & Yes/No \\
\hline & Condition of dwelling units \& other sheds such as kitchen, cattle sheds & Positive & Likert \\
\hline & Condition of sanitary latrines & Positive & Likert \\
\hline \multirow{11}{*}{$\begin{array}{l}\text { Socio-economic } \\
\text { vulnerability (11) }\end{array}$} & Amount paid to buy water from Private /NGOs developed water plant & Positive & Taka \\
\hline & Disconnected from extended family members/relatives/friends & Positive & Yes/No \\
\hline & Excluded from the community & Positive & Yes/No \\
\hline & Having seasonality effect on household income and consumption & Positive & Yes/No \\
\hline & $\mathrm{HH}$ head/adult members engage in hazardous and risky activities & Positive & Yes/No \\
\hline & Existence of women insecurity at both household and community level & Positive & Yes/No \\
\hline & Child labour in the family & Positive & Yes/No \\
\hline & Having disability/chronically illness in the family. & Positive & Count \\
\hline & Access to social safety nets program & Negative & Count \\
\hline & Amount of remittance support & Negative & Taka \\
\hline & Amount of loan & Positive & Taka \\
\hline \multirow{9}{*}{$\begin{array}{l}\text { Political } \\
\text { vulnerability (09) }\end{array}$} & $\mathrm{HH}$ heads and adult members have lack of mobility in community activities & Positive & Yes/No \\
\hline & Tenure insecurity & Positive & Yes/No \\
\hline & Political violence in the community & Positive & Yes/No \\
\hline & Political bias in distributing safety-nets & Positive & Yes/No \\
\hline & $\begin{array}{l}\text { Government development activities fail or have minimal effects on minimizing impacts } \\
\text { of climate induced hazards }\end{array}$ & Positive & Yes/No \\
\hline & Political influence in rehabilitation programs & Positive & Yes/No \\
\hline & Corruption of political leaders in post hazard reconstruction programs & Positive & Yes/No \\
\hline & Political bias in hazard time relief distribution & Positive & Yes/No \\
\hline & Do not have access to shelter project after disaster & Positive & Yes/No \\
\hline
\end{tabular}

